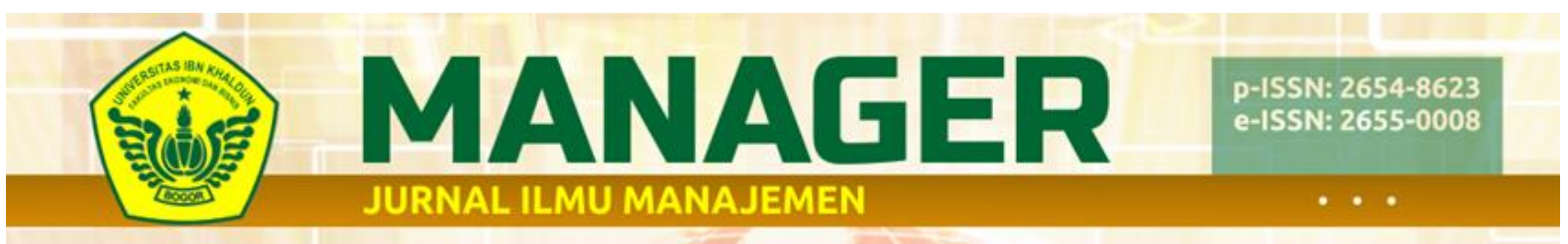

Vol. 3 No 1 Februari 2020 Hal 29- 39 @) (1) () http://ejournal.uikabogor.ac.id/index.php/Manager/index

\title{
PENGARUH NILAI TUKAR, INFLASI DAN SUKU BUNGA TERHADAP PROFITABILITAS KEUANGAN PERUSAHAAN SUB SEKTOR TELEKOMUNIKASI
}

\author{
Nur Fitriani Putri Lestari, Immas Nurhayati, Supramono \\ Fakultas Ekonomi dan Bisnis, Universitas Ibn Khaldun Bogor Indonesia \\ nurfitrianiputril@gmail.com, immasnurhayati1@gmail.com, \\ supramonouika@gmail.com
}

Absract

Being one of the most competitive business industries, telecommunication industry has become an important role in communicating every object and exchanging data. Therefore, sufficient funding is required to keep up with the latest technology and innovations in this business. This study aims to determine the effect of macro economic variables on profitability (ROA) of telecommunications sub-sector companies, namely exchange rates, inflation and interest rates. This study uses data from the annual financial statements of telecommunications sub-sector companies during 2009-2018 period and study of macroeconomic literature from the Bank Indonesia website. The method used is descriptive comparative. The result shows that, unlike the inflation and interest rates, the exchange rate has a significant influence on ROA, partially. Simultaneously, the exchange rate, inflation and interest rates have no significant effect on ROA. Whereas the independent variable consisting of exchange rates, inflation and interest rates can simultaneously interpret the ROA dependent variable of $7.7 \%$, the remaining $92.3 \%$ is explained by other variables excluding the exchange rate, inflation and interest rates.

Keywords: Inflation, Exchange Rates, Interest Rates, ROA

\begin{abstract}
Abstrak
Industri telekomunikasi adalah salah satu industri bisnis yang paling kompetitif, karena dengan adanya industri telekomunikasi setiap objek mampu berkomunikasi dan mampu bertukar data satu sama lain. Setidaknya perusahaan telekomunikasi harus mempunyai dana yang cukup besar untuk mengikuti inovasi teknologi terbaru. Penelitian ini bertujuan untuk mengetahui pengaruh variabel makro ekonomi terhadap profitabilitas (ROA) perusahaan sub sektor telekomunikasi. Variabel tersebut adalah nilai tukar, inflasi dan suku bunga. Penelitian ini menggunakan data dari laporan keuangan tahunan perusahaan sub sektor telekomunikasi periode tahun 2009-2018 dan studi literatur makro ekonomi dari website Bank Indonesia. Metode yang digunakan adalah deskriptif komparatif. Hasil penelitian menunjukkan bahwa secara parsial nilai tukar berpengaruh signifikan terhadap ROA. Inflasi dan suku bunga secara parsial tidak berpengaruh signifikan terhadap ROA. Dan secara simultan nilai tukar, inflasi dan suku bunga tidak berpengaruh signifikan terhadap ROA. Variabel bebas yang terdiri dari nilai tukar, inflasi dan suku bunga secara simultan dapat menjelaskan variabel terikat ROA sebesar 7.7\%, sedangkan sisanya 92.3\% dijelaskan oleh variabel lain diluar nilai tukar, inflasi dan suku bunga.
\end{abstract}

Kata kunci : Inflasi, Nilai Tukar, Suku Bunga, ROA 


\section{Pendahuluan}

\section{Latar Belakang}

Industri telekomunikasi adalah salah satu industri bisnis yang paling kompetitif dan berkembang pesat saat ini, karena dengan adanya industri telekomunikasi setiap objek mampu berkomunikasi dan mampu bertukar data satu sama lain. Setidaknya perusahaan telekomunikasi harus mempunyai dana yang cukup besar untuk mengikuti inovasi teknologi terbaru. Meski begitu dana yang besar tersebut tidak selalu diiringi dengan pendapatan yang tinggi. Bahkan terdapat beberapa perusahaan yang setiap tahunnya mengalami kerugian.

Perusahaan telekomunikasi di Indonesia cukup banyak melakukan impor produk telekomunikasi dari luar negeri yang tentunya diimpor dan dibayar dalam mata uang asing. Selain itu, sejumlah perusahaan telekomunikasi di Indonesia memiliki hutang dalam valuta asing yang cukup besar.

Menurut Miskhin (2008, hlm. 107) "Kurs (exchange rate) sebagai harga satu mata uang dalam mata uang yang lain."

Melemahnya nilai tukar berpotensi memberatkan kinerja perusahaan tersebut karena keperluan membayar utang bunga semakin tinggi.

"Suku bunga adalah ukuran keuntungan investasi yang dapat diperoleh pemilik modal dan juga merupakan ukuran biaya modal yang harus dikeluarkan oleh perusahaan atas penggunaan dana dari pemilik modal." (Ekananda, 2014, hlm. 234)

Di tengah kompetisi yang ketat saat ini, perusahaan telekomunikasi tidak mungkin menaikkan tariff sesukanya dan mengorbankan kualitas demi menghemat pengeluaran terlebih mekanisme penetapan tarif telah diatur oleh Badan Regulasi Telekomunikasi Indonesia (BRTI). Belum lagi tingkat inflasi dan suku bunga di Indonesia juga cenderung meningkat setiap tahunnya yang melemahkan daya beli masyarakat. "Inflasi adalah kenaikan harga barangbarang yang bersifat umum dan terusmenerus. Dari definisi ini, ada tiga komponen yang harus dipenuhi agar dapat dikatakan telah terjadi inflasi, yaitu kenaikan harga, bersifat umum, dan berlangsung terus-menerus." (Rahardja \& Manurung, 2008, hlm. 359)

Menurut Sutrisno (2013, hlm. 222) "Kinerja perusahaan merupakan rasio yang digunakan untuk mengukur efektivitas perusahaan dalam mendapatkan keuntungan."

Menurut Suharti (Suharti, 2012) "Melalui analisis keuangan dapat diketahui kondisi kinerja serta kesehatan keuangan perusahaan baik dari aspek internal maupun eksternal keuangan perusahaan.”

\section{Rumusan Masalah}

1. Apakah nilai tukar berpengaruh terhadap profitabilitas keuangan perusahaan?

2. Apakah inflasi berpengaruh terhadap profitabilitas keuangan perusahaan?

3. Apakah suku bunga berpengaruh terhadap Profitabilitas Keuangan Perusahaan?

4. Apakah nilai tukar dan inflasi berpengaruh terhadap profitabilitas keuangan perusahaan?

5. Apakah nilai tukar dan suku bunga berpengaruh terhadap profitabilitas keuangan perusahaan? 
6. Apakah Inflasi dan suku bunga berpengaruh terhadap profitabilitas keuangan?

7. Apakah nilai tukar, inflasi dan suku bunga berpengaruh terhadap profitabilitas keuangan?

\section{Metodologi Penelitian}

Penelitian ini merupakan penelitian deskriptif komparatif. Populasi dari penelitian ini adalah perusahaan telekomunikasi yang terdaftar di BEI periode 2009-2018. Teknik sampling yang digunakan adalah non probability sampling dengan menggunakan metode purposive sampling. Sumber data yang digunakan dalam penelitian ini adalah sekunder, yakni laporan keuangan tahunan perusahaan telekomunikasi periode 2009-2018.

\section{Analisis Rasio Profitabilitas}

Data kinerja keuangan perusahaan diperoleh dari kemampuan laba yang dihasilkan perusahaan (profitabiltas) dalam melakukan aktivitas usaha.

Dirumuskan :

$$
R O A=\frac{E A T}{\text { Total Assets }}
$$

\section{Kurs}

Data kurs yang digunakan adalah perubahan kurs tengah setiap akhir tahun. Kurs tengah diperoleh dari selisih nilai kurs jual dan kurs beli berdasarkan data kurs transaksi pada Bank Indonesia. Dirumuskan :

Kurs Tengah $=\frac{\text { Kurs Jual }+ \text { Kurs Beli }}{2}$

\section{Inflasi}

Data inflasi diperoleh dari perubahan indeks harga konsumen
(IHK) akhir tahun yang dihitung sebagai berikut:

$$
\text { Inflasi }=\frac{I H K t-I H K t_{-1}}{I H t_{-1}} \times 100 \%
$$

\section{Suku bunga}

Data BI rate diperoleh dari Bank Indonesia dengan indicator BI Rate yaitu suku bunga kebijakan yang mencerminkan sikap atau stance kebijakan moneter yang ditetapkan oleh bank Indonesia dan diumumkan kepada publik.

\section{Analisis Regresi Koefisien Korelasi}

Analisis koefisien korelasi merupakan suatu analisis yang mengukur kuat tidaknya variabel $\mathrm{X}$ dan variabel $\mathrm{Y}$, yang diukur dengan suatu nilai.

$r=\frac{n\left(\sum x y\right)-\left(\sum x\right)\left(\sum y\right)}{\sqrt{\left[\left(n \sum x^{2}\right)-\left(\sum x\right)^{2}\right] \times\left[\left(n \sum y^{2}\right)-\left(\sum y\right)^{2}\right]}}$

\section{Koefisien Determinasi}

Koefisien determinasi adalah kuadrat koefisien korelasi yang mengukur kedekatan hubungan hingga dapat diketahui pengaruh variabel $\mathrm{X}$ terhadap Y. Dirumuskan :

$$
\mathrm{KD}=\mathrm{r}^{2} \times 100 \%
$$

\section{Hasil dan Pembahasan}

\section{Analisis Regresi Berganda}

Analisis regresi berganda adalah suatu proses untuk memperoleh suatu hubungan fungsional antara variable 
acak Y dengan variabel $X$. Dirumuskan : $Y=a+\beta X 1+\beta X 2+\beta X 3$ individual/parsial. Sedangkan uji f untuk mengetahui pengaruh variabel independen secara bersama-sama

\section{A. Pengaruh nilai tukar terhadap profitabilitas (ROA)}

Tabel 1

Model Summary nilai tukar terhadap profitabilitas

Model Summary

\begin{tabular}{llrrr}
\hline Model & R & R Square & $\begin{array}{c}\text { Adjusted R } \\
\text { Square }\end{array}$ & $\begin{array}{l}\text { Std. Error of } \\
\text { the } \\
\text { Estimate }\end{array}$ \\
\cline { 1 - 4 } & $.249^{\mathrm{a}}$ & .062 & .043 & .60144 \\
\hline
\end{tabular}

\section{Uji Hipotesis $\mathbf{t}$ dan $\mathbf{f}$}

Uji t bertujuan untuk mengetahui pengaruh variabel independen terhadap dependen secara terhadap variabel dependen

Tabel 2.

Coefficients $^{a}$ nilai tukar terhadap profitabilitas

Coefficients ${ }^{\mathrm{a}}$

\begin{tabular}{|c|c|c|c|c|c|c|}
\hline \multirow{2}{*}{\multicolumn{2}{|c|}{ Model }} & \multicolumn{2}{|c|}{$\begin{array}{l}\text { Unstandardized } \\
\text { Coefficients }\end{array}$} & \multirow{2}{*}{$\begin{array}{c}\text { Standardized } \\
\text { Coefficients } \\
\text { Beta }\end{array}$} & \multirow[t]{2}{*}{$\mathrm{T}$} & \multirow[t]{2}{*}{ Sig. } \\
\hline & & B & Std. Error & & & \\
\hline \multirow[b]{2}{*}{1} & (Constant) & .692 & .487 & & 1.419 & .162 \\
\hline & $\begin{array}{l}\text { Nilai } \\
\text { Tukar }\end{array}$ & -7.319E-005 & .000 & -.249 & -1.785 & $.081 *$ \\
\hline
\end{tabular}

a. Dependent Variable: ROA

*Signifikan pada $\alpha 10 \%$

a. Predictors: (Constant), Nilai Tukar

Diperoleh nilai koefisien korelasi (R) sebesar 0.249 (24.9\%), hal ini menandakan variabel nilai tukar mempengaruhi kinerja keuangan perusahaan dengan kekuatan level hubungan $24.9 \%$. Nilai korelasi ini memiliki tingkat hubungan rendah.

Sedangkan untuk nilai koefisien determinasi $\left(\mathrm{R}^{2}\right)$ yang dapat diketahui melalui nilai $\mathrm{R}$ square sebesar 0.062
(6.2\%), hal ini artinya ROA di pengaruhi nilai tukar sebesar $6.2 \%$. Sementara itu sisanya $93.8 \%$ dijelaskan oleh variabel diluar nilai tukar, seperti current ratio, debt to equity ratio, working capital turn over, net profit margin, dll.

Berdasarkan tabel 2. dapat diketahui persamaan regresi untuk mengetahui pengaruh nilai tukar terhadap profitabilitas perusahaan yaitu sebagai berikut:

$\mathrm{Y}=0.692-0.00007319 \mathrm{X}$ 
Dimana : $\quad \mathrm{Y}=$ Profitabilitas

$$
\mathrm{X}=\text { Nilai Tukar Rupiah }
$$

Hasil persamaan regresi tersebut dapat disimpulkan sebagai berikut:

1. Koefisien regresi nilai tukar (X1) sebesar $\quad-0.00007319$ menyatakan bahwa setiap kenaikan nilai tukar sebesar 1 satuan akan menurunkan profitabilitas sebesar 0.00007319 . dari nilai koefisien regresi sebesar
0.00007319 menunjukkan terdapat pengaruh negatif variabel nilai tukar terhadap profitabilitas perusahaan.

2. Nilai t-hitung untuk nilai tukar sebesar -1.785 variabel ini memiliki nilai signifikansi 0.081 yang apabila dibandingkan dengan $\alpha \quad 10 \%$ (0.081<0.10). Maka Ho ditolak dan Ha diterima, artinya secara parsial nilai tukar mempengaruhi profitabilitas (ROA) secara signifikan.

\section{B. Pengaruh Inflasi terhadap Profitabilitas Keuangan}

Tabel 3.

Model summary inflasi terhadap profitabilitas

Model Summary

\begin{tabular}{rrrrrr}
\hline Model & $\mathrm{R}$ & R Square & $\begin{array}{c}\text { Adjusted R } \\
\text { Square }\end{array}$ & $\begin{array}{l}\text { Std. Error of } \\
\text { the } \\
\text { Estimate }\end{array}$ \\
\cline { 1 - 4 } & $.122^{\mathrm{a}}$ & .015 & -.006 & .616449 \\
\hline
\end{tabular}

3. Nilai t-hitung untuk nilai tukar sebesar -1.785 variabel ini memiliki nilai tukar mempengaruhi profitabilitas (ROA) secara signifikan. Diperoleh nilai koefisien korelasi (R) sebesar 0,122 $(12,2 \%)$, hal ini menandakan variabel inflasi mempengaruhi profitabilitas keuangan perusahaan dengan kekuatan level hubungan $12,2 \%$. Nilai koefisien ini memiliki tingkat hubungan sangat rendah.

Sedangkan untuk nilai koefisien determinasi $\left(\mathrm{R}^{2}\right)$ yang dapat diketahui melalui nilai $\mathrm{R}$ square pada tabel 3 . sebesar 0.015 (1.5\%), hal ini artinya ROA dipengaruhi oleh inflasi sebesar $1.5 \%$.

Sementara itu sisanya $98.5 \%$ dipengaruhi oleh variabel diluar inflasi, seperti current ratio, debt to equity ratio, working capital turn over, net profit perusahaan sub sektor telekomunikasi margin, dll. secara parsial dapat dilihat melalui tabel Pengaruh inflasi terhadap berikut. profitabilitas keuangan (ROA)

Tabel 4.

Coefficients ${ }^{\mathrm{a}}$ inflasi terhadap profitabilitas

Coefficients $^{\mathrm{a}}$

\begin{tabular}{|c|c|c|c|}
\hline Model & $\begin{array}{c}\text { Unstandardized } \\
\text { Coefficients }\end{array}$ & $\begin{array}{l}\text { Standardized } \\
\text { Coefficients }\end{array}$ & $\mathrm{T}$ \\
\hline
\end{tabular}




\begin{tabular}{|c|c|c|c|c|c|c|}
\hline & & B & Std. Error & Beta & & \\
\hline & (Constant) & -.331 & .214 & & -1.547 & .128 \\
\hline 1 & Inflasi & 3.475 & 4.085 & .122 & .851 & .399 \\
\hline
\end{tabular}

a. Dependent Variable: ROA

Berdasarkan tabel 4. dapat diketahui profitabilitas sebesar 3.475. dari persamaan regresi untuk mengetahui nilai koefisien regresi sebesar 3.475 pengaruh inflasi terhadap profitabilitas menunjukkan terdapat pengaruh perusahaan yaitu sebagai berikut: positif variabel inflasi terhadap

$\mathrm{Y}=-0.331+3.475 \mathrm{X}$

Dimana : Y = Profitabilitas

$$
\mathrm{X}=\text { Inflasi }
$$

profitabilitas perusahaan.

2. Nilai t-hitung untuk inflasi sebesar

signifikansi 0.399 yang apabila

Hasil persamaan regresi tersebut dapat dibandingkan dengan $\alpha 10 \%$ disimpulkan sebagai berikut: $(0.399>0.10)$ maka Ho diterima dan

1. Koefisien regresi Inflasi (X2) Ha ditolak, artinya secara parsial sebesar 3.475 menyatakan bahwa inflasi tidak mempengaruhi setiap kenaikan Inflasi sebesar 1 profitabilitas (ROA) secara satuan akan meningkatkan signifikan.

\section{Pengaruh Suku Bunga terhadap Profitabilitas Keuangan}

Tabel 5.

Model summary Suku Bunga terhadap profitabilitas

Model Summary

\begin{tabular}{lrrrrr}
\hline Model & R & R Square & $\begin{array}{c}\text { Adjusted R } \\
\text { Square }\end{array}$ & $\begin{array}{l}\text { Std. Error of } \\
\text { the } \\
\text { Estimate }\end{array}$ & \begin{tabular}{rrrr}
.621061 \\
\cline { 1 - 3 }
\end{tabular} \\
\hline
\end{tabular}

a. Predictors: (Constant), Suku Bunga

Berdasarkan tabel 5. dapat diketahui nilai koefisien korelasi (R) sebesar 0.007 $(0.7 \%)$, hal ini menandakan variabel suku bunga mempengaruhi profitabilitas keuangan perusahaan dengan kekuatan level hubungan $0.7 \%$. Nilai koefisien ini memiliki tingkat hubungan sangat rendah.
Sedangkan untuk nilai koefisien determinasi $\left(\mathrm{R}^{2}\right)$ yang dapat diketahui melalui nilai $\mathrm{R}$ square pada tabel 4.13 sebesar $0.000(0 \%)$, hal ini artinya tidak ada. profitabilitas (ROA) keuangan perusahaan yang dipengaruhi oleh inflasi 
Tabel 6.

Coefficients $^{a}$ Suku bunga terhadap profitabilitas

\section{Coefficients $^{\mathrm{a}}$}

a. Dependent Variable: ROA

\begin{tabular}{llrrrrr}
\hline Model & \multicolumn{2}{c}{$\begin{array}{l}\text { Unstandardized } \\
\text { Coefficients }\end{array}$} & \multicolumn{2}{c}{$\begin{array}{c}\text { Standardized } \\
\text { Coefficients }\end{array}$} & t & Sig. \\
& \multicolumn{2}{c}{ B } & Std. Error & Beta & & \\
\hline \multirow{2}{*}{1} & (Constant) & -.190 & .513 & & -.371 & .712 \\
& Suku Bunga & .409 & 8.058 & .007 & .051 & .960 \\
\hline
\end{tabular}

Berdasarkan tabel 6. dapat diketahui persamaan regresi untuk mengetahui pengaruh suku bunga terhadap profitabilitas perusahaan yaitu sebagai berikut:

$\mathrm{Y}=-0.190+0.409 \mathrm{X}$

Dimana : $\quad Y=$ Profitabilitas

$$
\mathrm{X}=\text { Suku Bunga }
$$

Hasil persamaan regresi tersebut dapat disimpulkan sebagai berikut:

1. Koefisien regresi suku bunga (X3) sebesar 0.409 menyatakan bahwa setiap kenaikan Inflasi sebesar 1 satuan akan

\section{Pengaruh Nilai Tukar dan Inflasi terhadap Profitabilitas}

Untuk menguji apakah variabel nilai simultan maka diperlukan uji signifikansi tukar dan inflasi berpengaruh terhadap simultan (uji-F). hasil pengujian tersebut profitabilitas (ROA) perusahaan secara dapat dilihat pada tabel berikut.

Tabel 7

Uji F (Anova) nilai tukar dan inflasi terhadap profitabilitas

ANOVA $^{\mathrm{a}}$

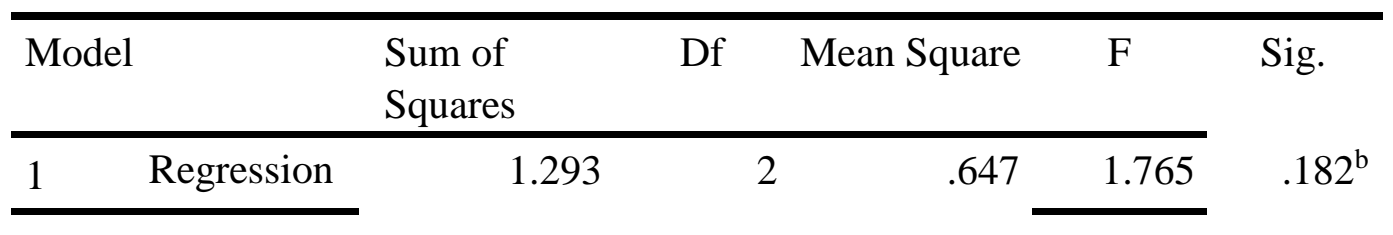




$\begin{array}{llll}\text { Residual } & 17.222 & 47 & .366 \\ \text { Total } & 18.515 & 49 & \end{array}$

a. Dependent Variable: ROA

b. Predictors: (Constant), Inflasi, Nilai tukar

Berdasarkan tabel 7 diketahui Diketahui nilai koefisien korelasi (R) signifikansi untuk uji tersebut sebesar sebesar 0.264 (26.4\%), hal ini menandakan 0.182 lebih besar dari a $10 \%$ nilai tukar dan inflasi memiliki kekuatan (0.182>0.10). Dari hipotesis ini, maka Ho untuk mempengaruhi profitabilitas (ROA) diterima dan Ha ditolak. Dengan sub sektor telekomunikasi sebesar $26.4 \%$ demikian maka dapat ditarik kesimpulan nilai korelasi ini memiliki tingkat bahwa nilai tukar dan inflasi secara hubungan rendah. Sedangkan untuk nilai bersama-sama/simultan tidak berpengaruh koefisien determinasi $\left(R^{2}\right)$ yang dapat signifikan terhadap profitabilitas (ROA) dilihat melalui $\mathrm{R}$ square memiliki nilai sub sektor telekomunikasi. Untuk $0.070 \quad(7 \%)$, hal ini artinya ROA mengetahui level hubungan dan besaran dipengaruhi oleh nilai tukar dan inflasi pengaruh nilai tukar dan inflasi terhadap profitabilitas (ROA) secara simultan dapat dilihat pada tabel berikut sebesar 7\%, sedangkan sisanya 93\% dijelaskan oleh variabel lain Profit margin, dll.

Tabel 8.

Coefficients $^{a}$ nilai tukar dan inflasi terhadap profitabilitas

\section{Coefficients $^{\mathrm{a}}$}

\begin{tabular}{|c|c|c|c|c|c|c|}
\hline \multirow{2}{*}{\multicolumn{2}{|c|}{ Model }} & \multicolumn{2}{|c|}{$\begin{array}{l}\text { Unstandardized } \\
\text { Coefficients }\end{array}$} & \multirow{2}{*}{$\begin{array}{c}\text { Standardized } \\
\text { Coefficients } \\
\text { Beta }\end{array}$} & \multirow[t]{2}{*}{$\mathrm{t}$} & \multirow[t]{2}{*}{ Sig. } \\
\hline & & B & Std. Error & & & \\
\hline \multirow{3}{*}{1} & (Constant) & .528 & .557 & \multirow{3}{*}{$\begin{array}{r}-.237 \\
.088\end{array}$} & .949 & .347 \\
\hline & Nilai tukar & $-6.951 \mathrm{E}-005$ & .000 & & \multirow{2}{*}{$\begin{array}{r}-1.667 \\
.620\end{array}$} & $.102 *$ \\
\hline & Inflasi & 2.515 & 4.053 & & & .538 \\
\hline
\end{tabular}

a. Dependent Variable: ROA

* Signifikan pada $\alpha 10 \%$

Untuk mengetahui besarnya pengaruh antara tingkat nilai tukar dan inflasi terhadap profitabilitas perusahaan dapat diketahu dari persamaan regresi yang diperoleh tabel diatas.

$\mathrm{Y}=0.528-0.00006951 \mathrm{X} 1+2.515 \mathrm{X} 2$

$$
\begin{array}{ll}
\text { Dimana : } & \mathrm{Y}=\text { Profitabilitas } \\
& \mathrm{X} 1=\text { Nilai Tukar } \\
& \mathrm{X} 2=\text { Inflasi }
\end{array}
$$

Hasil persamaan regresi tersebut dapat disimpulkan sebagai berikut: 
1. Koefisien regresi nilai tukar (X1) 0.0000695 artinya bahwa setiap kenaikan 1 satuan maka profitabilitas akan menurun sebesar 0.00006951 . dengan asumsi variabel lainnya dianggap konstan.
2. Koefisien regresi inflasi (X2) sebesar 2.515 menyatakan bahwa setiap kenaikan inflasi sebesar 1 satuan akan meningkatkan profitabilitas sebesar 2.515 satuan, dengan asumsi variabel lainnya dianggap konstan.

\section{E. Pengaruh Nilai Tukar dan Suku Bunga terhadap Profitabilitas}

Untuk menguji apakah variabel nilai $(0.220>0.10)$. dari hipotesis ini, maka Ho tukar dan suku bunga berpengaruh terhadap profitabilitas (ROA) perusahaan secara simultan maka diperlukan uji signifikansi simultan (ujiF). hasil pengujian tersebut dapat dilihat pada tabel berikut.
Berdasarkan tabel 9. diketahui diterima dan Ha ditolak. Dengan demikian maka dapat ditarik kesimpulan bahwa nilai tukar dan suku bunga secara bersamasama/simultan tidak berpengaruh signifikan terhadap profitabilitas (ROA) sub sektor telekomunikasi.

Tabel 9.

Uji F (Anova) Nilai Tukar dan Suku Bunga terhadap profitabilitas

\begin{tabular}{|c|c|c|c|c|c|c|}
\hline \multirow[t]{2}{*}{ Model } & & $\begin{array}{l}\text { Sum of } \\
\text { Squares }\end{array}$ & $\mathrm{df}$ & Mean Square & $\mathrm{F}$ & Sig. \\
\hline & Regression & 1.157 & 2 & .579 & 1.566 & $.220^{\mathrm{b}}$ \\
\hline \multirow[t]{2}{*}{1} & Residual & 17.358 & 47 & .369 & & \\
\hline & Total & 18.515 & 49 & & & \\
\hline
\end{tabular}

a. Dependent Variable: ROA

b. Predictors: (Constant), Suku Bunga, Nilai tukar

Tabel 10.

Model summary nilai tukar dan Suku bunga terhadap profitabilitas

Model Summary

\begin{tabular}{lrrrrr}
\hline Model & R & R Square & $\begin{array}{c}\text { Adjusted R } \\
\text { Square }\end{array}$ & \multicolumn{2}{l}{$\begin{array}{l}\text { Std. Error of } \\
\text { the } \\
\text { Estimate }\end{array}$} \\
\cline { 1 - 4 } & $.250^{\mathrm{a}}$ & .062 & .023 & .607723 \\
\hline
\end{tabular}

a. Predictors: (Constant), Suku Bunga, Nilai tukar

Signifikansi untuk uji tersebut sebesar 0.220 lebih besar dari a 10\% Untuk mengetahui level hubungan dan besaran pengaruh nilai tukar dan inflasi terhadap profitabilitas (ROA) secara simultan dapat dilihat pada tabel berikut.

Berdasarkan tabel 10. diketahui nilai koefisien korelasi (R) sebesar 0.250 
(25.0\%), hal ini menandakan nilai tukar dan suku bunga memiliki kekuatan untuk mempengaruhi profitabilitas (ROA) sub sektor telekomunikasi sebesar $25.0 \%$ nilai korelasi ini memiliki tingkat hubungan rendah. melalui $\mathrm{R}$ square memiliki nilai $0.062(6.2 \%)$, hal ini artinya profitabilitas

\section{Kesimpulan dan Saran}

\section{Kesimpulan}

a. Pengaruh nilai tukar terhadap profitabilitas perusahaan sub sektor telekomunikasi

Pengaruh nilai tukar terhadap profitabilitas yang diwakili ROA (Return On Assets) dengan nilai signifikansi $\quad 0.081<0.10$ maka Ho ditolak dan Ha diterima, artinya nilai tukar mempengaruhi profitabilitas (ROA) tidak signifikan. Korelasi senilai 0.249 dengan tingkat keeratan rendah dan Koefisien determinasi sebesar $6.2 \%$

b. Pengaruh Inflasi terhadap profitabilitas perusahaan sub sektor telekomunikasi

Pengaruh inflasi terhadap profitabilitas yang diwakili ROA (Return On Assets) dengan nilai signifikansi 0.399>0.10. Maka Ho diterima dan Ha ditolak, artinya inflasi tidak berpengaruh signifikan terhadap profitabilitas. Korelasi 0,122 dengan tingkat keeratan sangat rendah dan koefisien determinasi sebesar $1.5 \%$

c. Pengaruh suku bunga terhadap profitabilitas perusahaan sub sektor telekomunikasi

Pengaruh tingkat suku bunga terhadap profitabilitas yang diwakili ROA (Return On Assets) dengan nilai signifikansi 0.960>0.10. Maka Ho diterima dan Ha ditolak, artinya suku
(ROA) dipengaruhi oleh nikai tukar dan suku bunga sebesar $6.2 \%$, sedangkan sisanya $93.8 \%$ dipengaruhi oleh variabel lain, seperti current ratio, debt to equity ratio, working capital turn over, net profit margin.

bunga tidak tidak berpengaruh signifikan terhadap profitabilitas. Korelasi 0.007 dengan tingkat keeratan sangat rendah dan koefisien determinasi $0 \%$

d. Pengaruh nilai tukar dan inflasi terhadap profitabilitas perusahaan sub sektor telekomunikasi

Pengaruh nilai tukar dan inflasi terhadap profitabilitas yang diwakili ROA (Return On Assets) dengan nilai signifikansi 0.182>0.10. Maka Ho diterima dan Ha ditolak, artinya nilau tukar dan inflasi secara simultan tidak berpengaruh signifikan terhadap profitabilitas. Korelasi 0.264 dengan tingkat keeratan rendah dan koefisien determinasi sebesar 7\%

e. Pengaruh nilai tukar dan suku bunga terhadap profitabilitas perusahaan sub sektor telekomunikasi

Pengaruh tingkat nilai tukar dan suku bunga terhadap profitabilitas yang diwakili ROA (Return On Assets) dengan nilai signifikansi $0.220>0.10$. Maka Ho diterima dan $\mathrm{Ha}$ ditolak, artinya nilai tukar dan suku bunga secara simultan tidak berpengaruh signifikan terhadap profitabilitas. Korelasi 0.250 dengan tingkat keeratan rendah dan koefisien determinasi sebesar $6.2 \%$.

f. Pengaruh inflasi dan suku bunga terhadap profitabilitas perusahaan sub sektor telekomunikasi 
Pengaruh inflasi dan suku bunga terhadap profitabilitas yang diwakili ROA (Return On Assets) dengan nilai signifikansi $0.592>0.10$. Maka Ho diterima dan Ha ditolak, artinya inflasi dan suku bunga secara simultan tidak berpengaruh signifikan terhadap profitabilitas. Korelasi 0.149 dengan tingkat keeratan sangat rendah dan koefisien determinasi sebesar $2.2 \%$

g. Pengaruh nilai tukar, inflasi dan suku bunga terhadap profitabilitas perusahaan sub sektor telekomunikasi

Pengaruh nilai tukar, inflasi dan suku bunga terhadap profitabilitas yang diwakili ROA (Return On Assets) dengan nilai signifikansi $0.290>0.10$. Maka Ho diterima dan $\mathrm{Ha}$ ditolak, artinya nilai tukar, inflasi dan suku bunga secara simultan tidak berpengaruh signifikan terhadap profitabilitas. Korelasi 0.278 dengan tingkat keeratan rendah dan koefisien determinasi sebesar $7.7 \%$

\section{Saran}

h. Perusahaan sub sektor telekomunikasi yang terdaftar di BEI lebih memperhatikan faktor-faktor lain seperti faktor internal perusahaan untuk meningkatkan profitabilitas perusahaan karena faktor eksternal makro ekonomi (nilai tukar, inflasi dan suku bunga) tidak memberikan pengaruh yang signifikan terhadap profitabilitas (ROA) perusahaan sub sektor telekomunikasi.

i. Diharapkan untuk penelitian selanjutnya dapat memperluas objek penelitian dari segi waktu triwulan atau data yang lebih dari 10 tahun agar hasilnya lebih menggambarkan kondisi yang ada juga memberikan hasil yang lebih komprehensif.

j. Pengukuran profitabilitas indicator ROA dalam penelitian ini belum merefleksikan kemampuan perusahaan dalam menghasilkan laba. Oleh karena itu sebaiknya penelitian selanjutnya dapat memperhatikan pengukuran profitabilitas lainnya seperti NPM, GPM atau ROE.

\section{Daftar Pustaka}

Ekananda, M. (2014). Internasional. Jakarta: Erlangga.

Mishkin, F. S. (2008). Ekonomi Uang, Perbankan, dan Pasar Keuangan (8 ed.). Jakarta: Salemba Empat.

Rahardja, P., \& Manurung, M. (2008). Pengantar Ilmu Ekonomi. Jakarta: Lembaga Penerbit Universitas Indonesia.

Suharti, T. (2012). Peranan Analsis Rasio Keuangan Untuk Menilai Keuangan. https://doi.org/10.32832/inovat or.v1i2.174

Sutrisno. (2013). Manajemen Keuangan Teori, Konsep dan Aplikasi. Yogyakarta: Ekonisia. 